\title{
La controversia sobre la tributación de las mujeres recogidas en Filipinas a mediados del siglo XVIII. El caso del recogimiento de Santa Rita de Pásig
}

\author{
Marta Ma MANCHADO LÓPEZ \\ Universidad de Córdoba \\ hi1malom@uco.es
}

Recepción: 15 de noviembre de 2013 / Revisión: 20 de diciembre de 2013

Aceptación: 8 de enero de 2014 / Publicación: Diciembre de 2015

\begin{abstract}
RESUMEN
El presente trabajo está dedicado al recogimiento para indias y mestizas, establecido en el pueblo de Pásig en 1740, y a la disputa sobre la obligación del pago de tributos que afectaba a las mujeres recogidas o "beatas". Fundación surgida al margen del Real Patronato, dicho recogimiento ejercía una enorme capacidad de atracción como lugar de reclusión voluntaria y casa de enseñanza. El contencioso sobre el pago del tributo sacaría a la luz recelos e intereses contrapuestos de las partes implicadas, al tiempo que evidenciaba el problema de fondo: la indefinición jurídica tradicional de este tipo de fundaciones en las islas. La solución que se le dio al problema (exención de tributos) se haría extensiva a otros centros similares de Filipinas. Este trabajo es, por tanto, una aportación al conocimiento del mundo de las mujeres en el archipiélago filipino, ámbito aún insuficientemente estudiado y de una gran complejidad. Se ha realizado a partir de documentación inédita del Archivo General de Indias.
\end{abstract}

Palabras clave: Historia de la mujer, recogimientos, beaterios, Pásig, tributos, Filipinas, siglo XVIII.

\author{
Controversy over the Taxation of Recogidas in the Philippines in the \\ mid-18th Century. The Case of Santa Rita de Pasig's Spiritual Absorption
}

\begin{abstract}
This article studies the house of seclusion established for devout Indian and mestizo laywomen in the town of Pasig in 1740, and the dispute over tribute obligations that affected retreated or "pious" women. Founded outside of the Royal Patronato, this house of seclusion was extraordinarily attractive as a place for voluntary retreat and as an educational center. The dispute over tribute payments brought to light misgivings and conflicts of interest between the parties involved, while revealing the fundamental problem: the traditionally undefined juridical status of this type of establishment on the Islands. The solution given to the problem (tribute exemption) was to be extended to other similar centers in the Philippines. This article, realized with the use of unpublished documentation from the General Archives of the Indies, contributes therefore to our knowledge of the world of women in the Philippine archipelago; an ambit of great complexity that, as of yet, has been insufficiently studied.
\end{abstract}


Keywords: History of Women, Retreats, Houses of Seclusion, Pasig, Tribute, Philippines, $18^{\text {th }}$ Century.

Sumario: 1. Introducción. 2. La fundación y evolución del recogimiento. 3. La numeración de los tributos de la provincia de Tondo y el planteamiento del problema. 4. La disputa en torno a la exención del tributo. 5. La visita de la casa de recogidas. 6. El debate sobre el futuro del recogimiento. 7. La resolución de la audiencia de Manila. 8. El asunto en el Consejo de Indias y la resolución del contencioso. 9. Conclusiones. 10. Referencias bibliográficas.

\section{INTRODUCCIÓN}

El mundo de la mujer en Filipinas ha sido escasamente abordado por los historiadores. Consecuencia de ello es que las publicaciones relativas a aspectos tales como su educación y espiritualidad sean aun hoy muy escasas. El presente trabajo se inscribe en una línea de investigación centrada en los recogimientos y beaterios filipinos, como experiencias de vida comunitaria en las que las mujeres indias, mestizas y chinas, que no eran admitidas a la vida conventual, podían encauzar sus inquietudes espirituales ${ }^{1}$. Muy valorados por la sociedad en que se insertaban y que contribuía a su sostenimiento, fueron cuestionados por las autoridades civiles, a cuyo control solían escapar, y mirados con recelo por las órdenes religiosas. La propia Corona se resistió a reconocerlos como beaterios y los mantuvo y fomentó siempre en calidad de recogimientos ${ }^{2}$. En estas fundaciones la vida de las mujeres discurría en una tensión permanente entre la vocación de aislamiento y la apertura hacia la sociedad, manifiesta fundamentalmente en su dimensión educativa ${ }^{3}$. El presente trabajo, realizado a partir de documentación inédita del Archivo General de Indias, está dedicado al recogimiento para indias y mestizas, establecido en el pueblo de Pásig y a la disputa sobre la obligación del pago de tributos que afectaba a las mujeres recogidas o "beatas"4.

1 Frutos de dicha línea de investigación son, entre otros: MANCHADO, 1999a, pp. 171-202; 1999b, pp. 485511; 2012, pp.1-16.

2 Sobre la distinta naturaleza de beaterios y recogimientos, véase BoRgEs, 1992a, pp. 233-234 y 1992b, pp. 307-312; Martínez Cuesta, 1993, pp. 511-529. Una apretada síntesis sobre estas fundaciones, en Camacho, 2007, pp. 367-390. Véase también SANTIAGO, 2005.

3 Este parece haber sido también el caso del recogimiento fundado en México por doña Catalina de Bustamante con el apoyo del virrey don Antonio de Mendoza y del arzobispo fray Juan de Zumárraga. En él se impartía enseñanza a las niñas indígenas y, aunque fracasó, queda como el primer intento de instrucción de la mujer indígena mexicana. LuQuE, 1970, pp. 279-298. Para situar en un contexto más amplio estas fundaciones, véase OlaEchea Labayen, 1970.

4 No es el propósito de este trabajo realizar una comparación con instituciones similares existentes en otros territorios de las Indias, cuestión que desbordaría los límites espaciales de este artículo, pero sí conviene señalar, entre otros, los importantes estudios de Josefina MuRIEL, o los contenidos en el volumen coordinado por Manuel Ramos Medina, 1995. 


\section{LA FUNDACIÓN Y EVOLUCIÓN DEL RECOGIMIENTO}

La casa para mujeres recogidas de Pásig fue creada a instancias de una viuda india, por el ministro doctrinero del pueblo, el agustino calzado fray Félix Trillo, en 1740. Estaba destinada a indias y mestizas pobres y tenía diversos usos, fundamentalmente la enseñanza de niñas, tarea a la que él solo no podía hacer frente. También era un lugar seguro para aquellas mujeres "que por varias causas no podían estar a su libertad en el pueblo"s. Se trataba de mujeres de vida escandalosa y de otras que huían de un matrimonio concertado por los padres y que a ellas les desagradaba, o que querían casarse contra la voluntad paterna. No faltaban casos de jóvenes acosadas por sus padrastros y, por supuesto, de otras que anhelaban una vida religiosa y se sentían frustradas al no ser recibidas en el convento de Santa Clara de Manila ${ }^{6}$.

La casa muy pronto se convirtió en un foco de atracción para las mujeres de los pueblos próximos que acudían a los ejercicios espirituales que se realizaban anualmente. Asimismo, se implantó la costumbre entre las jóvenes casaderas de recogerse en dicha casa tres semanas antes de que tuviera lugar la celebración del matrimonio, para recibir la instrucción necesaria para ejercer como una buena casada cristiana.

En la casa de Pásig habitaban, pues, las niñas educandas, las mujeres confinadas por el religioso para apartarlas de una mala vida o para protegerlas, y otras que se habían retirado voluntariamente con la intención de llevar una vida de intensa piedad. Estas recibieron el nombre de "beatas" y, en consecuencia, la casa fue conocida como "beaterio de Santa Rita" o de Pásig. No vivían bajo clausura pero, eso sí, no estaba permitido el acceso a la casa a ningún varón. Tampoco realizaban votos, sino las que voluntariamente querían vivir en castidad, teniendo éstos, por lo tanto, un carácter personal o temporal. En consecuencia, eran libres de entrar y salir para acudir a la iglesia, curarse en caso de necesidad o tomar estado. Sobre su vestido habitual llevaban un escapulario que las identificaba como mantelatas (terciarias) agustinas y que evidenciaba su deseo de vivir sujetas a esta Orden, y "gozar de sus indulgencias y privilegios"7.

Su modo de vida era muy austero, por lo que los gastos de la casa eran pocos. Acostumbradas, por su condición de mujeres pobres, a las estrecheces, vivían conformes con el fruto de su trabajo y algunas limosnas. La fama de su vida virtuosa atrajo a la casa a un número creciente de mujeres y movió el corazón de personas generosas dispuestas a contribuir a su manutención ${ }^{8}$. Este fue el origen de una renta de 2.000 pesos con que se las quiso socorrer, pero de cuyo cobro no hay constancia.

5 Fray Félix Trillo al arzobispo de Manila. Pásig, 2-VII-1753. AGI, Filipinas, 300, N. 55.

6 Además de dicho convento, existían entonces en Manila y sus alrededores los "beaterios" de la Compañía (el más antiguo, fundado en 1685), Santa Catalina de Sena (1696), San Sebastián de Calumpang (1725), y Santa Rosa, también conocido como beaterio de la madre Paula (1750). De todos ellos sólo el de Santa Catalina acogía exclusivamente a españolas o mujeres "tenidas por tales", aunque sí recibía pupilas indias y mestizas. Los restantes nacieron para indias o mujeres de otras razas que no tenían posibilidad de profesar en un convento ya que el único femenino existente, Santa Clara, no las admitía.

7 Fray Félix Trillo al arzobispo de Manila. Pásig, 2-VII-1753. AGI, Filipinas, 300, N. 55.

8 El beaterio de Santa Rita de Pásig contó con importantes benefactores, como doña María Rita González del Rivero y Quijano, segunda marquesa de Monte Castro y Llanahermosa, y su esposo, don Pedro González del Rivero. 
En 1753, trece años después de su erección, en la casa vivían o se formaban más de 110 personas, entre mantelatas, recogidas, penitenciadas y niñas educandas. Fue entonces cuando fray Félix Trillo decidió que había llegado el momento de pedir licencia al rey para cambiar su estatus jurídico y convertirla formalmente en un beaterio o en un convento. Para ello solicitó informes al arzobispo, al gobernador y a la ciudad de Manila sobre la utilidad de dicha casa y la conveniencia de acceder a las pretensiones del religioso 9 . En realidad, la fundación se había realizado sin respetar las formalidades impuestas por las leyes y por eso la petición de fray Félix era doble, ya que suponía la aprobación real de lo realizado y la licencia para su transformación en una fundación diferente.

Los tres informes solicitados fueron redactados en el mes de julio de 1753 y en todos se alababa la utilidad de la casa y el ejemplo que daban las mujeres allí recogidas, pero discrepaban en lo relativo a las pretensiones de su fundador. La ciudad de Manila, por su parte, ponderó el régimen de vida que seguían y su labor de enseñanza, que beneficiaba a niñas de toda la provincia de Tondo, al tiempo que lo consideraba un modelo que debía seguirse en otras como útil remedio para el gran número de mujeres indias que no podían contraer matrimonio ni tenían lugar donde dedicarse a la vida religiosa. El acusado desequilibrio existente en el reparto de los sexos en la población indígena y mestiza colocaba a las mujeres en una situación de riesgo, por lo que los recogimientos se constituían en el único remedio aceptable. En ellos encontraban un oficio (maestras) y quedaban preservadas de los peligros del mundo. Su ejemplo, además, podía llevar a enmendarse a otras mujeres recluidas allí para su castigo o corrección. Ahora bien, si el rey prefería autorizar la fundación de un convento "sería muy del agrado de Dios, pues [es] lastimosa cosa que habiendo tantas en las islas capacísimas de lograr la mayor virtud, no tengan las desdichadas un convento donde poderlo conseguir" 10 .

Los informes del arzobispo y el gobernador son prácticamente idénticos en su contenido y en su forma. Ambos elogiaron la fundación de fray Félix Trillo y ambos defendieron su mantenimiento, pero como una mera casa de recogidas; es decir, apoyaban la concesión de la licencia real para subsanar los defectos de la fundación, pero se opusieron abiertamente a su transformación en beaterio. La casa debía permanecer como un recogimiento para educar a las niñas del pueblo, cuyo número debía limitarse a cuarenta. Allí se formarían hasta tomar estado "con aquella estabilidad y firmeza que traen las virtudes y buenas costumbres" ${ }^{11}$. Así se garantizaría su manutención y se evitaría privar a sus padres del servicio que las jóvenes podían prestarles en su ancianidad. En su condición de recogimiento, la casa quedaría bajo la jurisdicción del

\footnotetext{
9 Las cartas de fray Félix dirigidas al gobernador y al arzobispo están fechadas en Pásig, a 2-VII-1753. AGI, Filipinas, 300, N. 55.

10 La ciudad de Manila, al rey. Manila, 10-VII-1753. AGI, Filipinas, 300, N. 55.

11 El gobernador de Filipinas, don Francisco José de Ovando y Solís, marqués de Ovando, al rey. Manila, 11-VII-1753. AGI, Filipinas, 300, N. 55. Don Francisco José de Ovando fue nombrado gobernador de Filipinas por real provisión firmada en Buen Retiro, a 4-X-1746 (AGI, Filipinas, 342, L.11, ff. 220v-227v). Sirvió esta plaza hasta 1754, siendo sucedido en ella por don Pedro Manuel de Arandía (1754-1759). Molina, 1984. Una apretada síntesis del gobierno de Ovando en Ortiz de LA TABLA, 1974.
} 
ordinario y no de la orden de los agustinos calzados, y sometida en su funcionamiento al Real Patronato; es decir, a la autoridad del gobernador.

No era esta una cuestión baladí ya que, como expresamente se indica, de no ser así podían suscitarse controversias de carácter jurisdiccional. Un ejemplo reciente era el pleito originado en torno al beaterio de Santa Catalina de Sena, de Manila, causado por la voluntad de una beata de abandonarlo, a pesar de los votos profesados. El enfrentamiento entre el arzobispo y la orden de Santo Domingo, bajo cuya dirección estaban las beatas, provocó gran revuelo en las islas. El primero, fray Pedro de la Santísima Trinidad Martínez de Arizala, insistía en que la casa debía estar bajo la autoridad del diocesano, a lo que se negaban los religiosos alegando privilegios y exenciones ${ }^{12}$. El debate sobre la naturaleza de los votos profesados (definitivos o temporales) no era ajeno al empeño de los dominicos en transformar la casa en un convento. El asunto terminó en un contencioso que en 1754 aún estaba pendiente de resolución en el Consejo de Indias, y que no se cerraría hasta $1762^{13}$. De aquí que ahora el arzobispo intentara conjurar la ocasión de un nuevo enfrentamiento puesto que el anterior le había procurado grandes disgustos; y ya que en el asunto del beaterio de Santa Catalina lo que se debatía en el fondo era un doble conflicto jurisdiccional (civil-eclesiástico y entre el diocesano y la orden de Santo Domingo), ahora, en lo relativo al intento de fray Félix Trillo, puso buen cuidado en exponer claramente los peligros de condescender. Esto explica no sólo los argumentos arzobispales sino su perfecta sintonía, en fondo y forma, con el gobernador.

Fray Félix Trillo elevó su petición al rey, previa obtención de la correspondiente patente del definitorio de la Provincia del Santísimo Nombre de Jesús. En ella, su orden le autorizaba a solicitar la erección del beaterio o de un convento. El escrito de fray Félix abundó en los argumentos que ya conocemos, añadiendo algunos detalles como la eficacia en la redención de "mujeres inquietas y escandalosas", muchas de las cuales no querían abandonar nunca la casa, o la sobresaliente labor catequética que realizaban las recogidas, quienes con sus enseñanzas lograban "lo que no han podido los más celosos ministros". Asegura también que no pasaban necesidad y que se mantenían con el fruto de su trabajo y algunas "tierrecillas" que tenían de sus padres, y también apunta a la voluntad de personas devotas de beneficiarlas con algunas rentas. En su petición se refiere a un beaterio, pero deja manifiesto que muchas personas aceptarían de buena gana que el rey prefiriera un convento femenino ${ }^{14}$.

Esta petición llegó al Consejo de Indias en agosto de 1754 y pasó a informe del fiscal junto con las cartas escritas por el gobernador y por la ciudad de Manila. La correspondiente al arzobispo llegó más tarde, una vez que aquel ya había elaborado su informe. En él había dejado constancia de que faltaba el del metropolitano y de que los recibidos obviaban el punto fundamental, que era el detalle de los fondos con los

12 El arzobispo había tomado posesión de su sede en 27 de agosto de 1747 y la ocupó hasta su fallecimiento, en 28 de mayo de 1755. La sede había permanecido vacante durante cinco años, a la muerte de fray Juan Ángel Rodríguez (24 de junio de 1742).

13 Sobre el establecimiento, historia y peripecias vividas por dicha fundación, particularmente los conflictos jurisdiccionales y canónicos, véase MANCHADO, 2002, pp.277-288.

14 Fray Félix Trillo, al rey. S.1, s.f. Patente del definitorio de la provincia del Santísimo Nombre de Jesús. Tondo, 4-VII-1753. AGI, Filipinas, 300, N. 55. 
que contaba la casa para su sustento. Era esta una preocupación recurrente cuando se proponía alguna fundación de esta naturaleza y con ello no sólo se trataba de evitar que resultara gravosa para la real hacienda, sino también que afectara negativamente al convento de Santa Clara de Manila y a otras instituciones que se sostenían de limosnas.

No obstante, manifestó su opinión opuesta frontalmente a la conversión de la casa en beaterio, y "mucho menos" en convento. Alegaba que la utilidad que proporcionaba el recogimiento cesaría y terminaría por ser para las indias más acomodadas. En el estado en que se encontraba, se adaptaba a la ley 19 , título $3^{\circ}$, libro I de la Recopilación, que ordenaba a los virreyes fomentar (y fundar en el caso de que no las hubiere) casas para doctrinar en la fe y educar a doncellas indias, bajo la supervisión de "matronas de buena vida y ejemplo". Se trataba de procurar que su influencia se extendiera por todas las provincias y fomentara la instrucción y la cristianización, ambas en castellano. Estando la casa de Pásig de acuerdo con dicha ley, lo que procedía era que se conservara en la misma forma, bajo el cuidado vigilante del gobernador.

El Consejo de Indias asumió el dictamen fiscal y elevó la consulta al rey ${ }^{15}$. La real cédula resolutiva sobre este asunto fue firmada en Buen Retiro, a 17 de noviembre de 1754; en ella se agradecía al padre Trillo su celo en el establecimiento de la casa pero se le negaba la licencia para transformarla en beaterio. La voluntad real era que permaneciera ajustada a la mencionada ley y, por tanto, bajo la protección del gobernador, que ejercía como vice-patrono ${ }^{16}$. Esta real cédula llegó a Filipinas en mayo del siguiente año. Por entonces la cuestión relativa a la naturaleza jurídica de la fundación había cobrado nueva importancia con ocasión de la numeración de tributos que se realizó en la provincia de Tondo.

\section{LA NUMERACIÓN DE LOS TRIBUTOS DE LA PROVINCIA DE TONDO Y EL PLANTEAMIENTO DEL PROBLEMA}

En 1754 se realizó en la provincia de Tondo una nueva numeración de tributos por cuenta abierta y padrón de habitantes ${ }^{17}$. El promotor fiscal comisionado al efecto informó al justicia mayor de la provincia de que no habían sido incluidas en el padrón del pueblo de Pásig las mujeres que vivían en el recogimiento. Había preguntado al padre prior del pueblo sobre lo que se había hecho en anteriores numeraciones, pero por toda respuesta obtuvo de él que "no las tomaron en la boca para dicho fin". Fray Félix Trillo tampoco le había presentado documento alguno que acreditara tal cosa, ni

15 El asunto fue visto por primera vez en el Consejo de 22-VIII-1754, que lo remitió al fiscal. Vista del fiscal del Consejo de Indias. Madrid, 3-IX-1754. Acuerdo del Consejo de Indias. Madrid, 19-IX-1754. Todos en AGI, Filipinas, 300, N. 55.

16 Traslado de esta real cédula se encuentra en AGI, Filipinas, 160, N. 5 y en AGI, Filipinas, 335, L. 16, ff.333v-335v. Ha sido publicada por RodRíGuez, 1979, p. 268.

17 Sobre los sistemas de cuenta cerrada y cuenta abierta, y su aplicación en el siglo XVIII en Filipinas, véase GARCíA-ABÁSOLO, 1991, pp.23-37. Según el propio gobernador Ovando él reimplantó el sistema de tributación por cuenta abierta y padrón de habitantes, que su antecesor, fray Juan de Arechederra y Tovar (obispo de la Nueva Segovia y gobernador interino de las islas) había sustituido por la cuenta cerrada. AGI, Filipinas, 301, N. 1. Véase también CosAnO, 1985. 
que explicara la razón de esta exención ${ }^{18}$. El justicia mayor de la provincia, que ostentaba además el oficio de contador y numerador de los reales tributos de ella, ordenó despachar un ruego y encargo al religioso pidiendo que exhibiera los documentos que reservaban del pago de tributos a las mujeres que vivían en la casa. Se inició así un procedimiento administrativo que no se cerrará hasta dejar manifiesta la condición jurídica del llamado beaterio y las razones de tal exención ${ }^{19}$.

La respuesta de fray Félix Trillo está a medio camino entre la ingenuidad y el hábil recurso a los hechos consumados, frecuente en los asuntos filipinos. Así, reconoció sin ambages que no disponía de documento alguno en que constara la exención, y esto por dos razones: nunca habían sido incluidas en un padrón de tributantes, y tanto el gobernador y sus antecesores, como el arzobispo habían visitado la casa y habían manifestado su satisfacción. Las alabanzas que habían vertido todos ellos sobre la vida ejemplar de las mujeres allí recogidas fueron entendidas como una aprobación suficiente de todo lo obrado. De ahí que jamás se le hubiera ocurrido procurarse los documentos que ahora parecían tan esenciales. Únicamente cuando concibió la idea de convertir la casa en beaterio o en convento, lo que había sucedido el año anterior, se puso manos a la obra y pidió al gobernador, al arzobispo y a la ciudad informes en apoyo de su pretensión. La respuesta del rey no había llegado aún, pero fray Félix manifestó su seguridad en que sería favorable, como aseguraba, le constaba. Sorprende en este punto la franqueza con la que el religioso expresa su deseo de transformación del recogimiento en un "monasterio de religiosas de puras indias" (deseo que no había manifestado abiertamente en su carta al rey), y más aún su confianza en que sería autorizado ${ }^{20}$.

No desaprovechó la ocasión fray Félix para evidenciar que el asunto de los tributos era, en realidad, de poco alcance ("más el ruido que las nueces"), porque si bien era cierto que en la casa había más de cien mujeres, solamente podía llamarse beatas a seis; siendo esto así, su inclusión en el padrón y el consiguiente pago de los tributos reportaría muy poco beneficio a la real hacienda. Según afirma, todas las demás eran menores de edad (y por tanto exentas), mientras que otras beatas no residían en la casa por haber salido para atender a sus padres. Estas habían sido numeradas normalmente y pagaban, por tanto, el tributo que les correspondía. Lo mismo sucedía con el resto de las mujeres que, por diversas causas, habían sido recogidas en la casa.

18 Eran tributantes todos los indios, hombres y mujeres útiles para trabajar y que estuvieran comprendidos entre los 20 y los 60 años. Quedaban exceptuados los mestizos de español, los inhábiles para trabajar, las poblaciones recién conquistadas (durante diez años), los cabezas de barangay, sus mujeres e hijos primogénitos durante el tiempo en que aquellos permanecían en el cargo, y aquellas comunidades que por circunstancias excepcionales (desastres naturales, ataques de enemigos) se encontraban en situaciones muy difíciles. Entre 1750 y 1775 la tasa permaneció invariable: un peso para el rey y dos tomines para el real situado, más una ganta de arroz limpio como donativo. Según Cosano, se trataba de un ramo regresivo ya que no se aprecia un aumento significativo de año en año. CosAno, 1985. Sobre la estructura del tributo y su monto en el siglo XVIII, véase Alonso, 2009, pp. 207-220.

19 Auto de don José de Artiaga, justicia mayor de la provincia de Tondo. Pásig, 25-I-1754. AGI, Filipinas, 198 , N. 15 .

20 Respuesta de fray Félix Trillo al ruego y encargo. Pásig, 28-I-1754. AGI, Filipinas, 198, N. 15. 
La multitud consta de niñas huérfanas y otras a quienes han puesto sus padres para su educación; de cuatro o cinco locas, que por abusar de ellas picarones, las metí en el beaterio, y meteré cuantas encuentre; de mujeres que están allí para casarse y de otras muchas violentas que tienen sus padres y a veces el señor arzobispo y yo por su poco sano proceder, pero todas estas están también en el padrón de su majestad y pagan el tributo $^{21}$.

Dos días después de responder al ruego y encargo, y tal y como anunciaba en él, fray Félix acudió al gobernador en demanda de protección para el recogimiento. Don Francisco de Ovando había estado en Pásig y lo conocía y aprobaba; resultó fácil recurrir a ello para alertarle de la amenaza que se cernía sobre su tranquilidad. Para fray Félix, querer numerar a las beatas para hacer que pagaran el tributo era una conjura del Infierno movida por la envidia que suscitaban los buenos frutos cosechados. Según afirmó en su carta, el caso no contaba con precedentes porque nunca se había numerado a las mujeres recogidas en otras casas de Manila, ni siquiera antes de que fueran aprobadas las fundaciones por el rey. Siendo esto así, y estando pendiente la solicitud hecha al monarca para que autorizara la transformación de la casa de Pásig en el convento para indias que soñaba fray Félix, no era lógico hacer la pretendida numeración. Tampoco lo parecía cuando el gobernador, el arzobispo y la propia ciudad habían escrito en favor del mantenimiento de la casa. Por otro lado, empadronar a las beatas reportaría a la real hacienda un ingreso exiguo, a cambio de grandes males: el disgusto del rey y del mismo Dios que recibía complacido las oraciones que aquellas le ofrecían por el monarca y todo su reino. En un arranque de vehemencia, fray Félix afirmó que era "querer juntar el cielo con la tierra, unir el espíritu con la carne y servir a Dios y al mundo", un empeño imposible 22 .

Pero más allá de la apasionada defensa hecha por este religioso, resultaba evidente que, por un lado, la fundación se había hecho al margen del Real Patronato y de sus leyes; por otro, que las mujeres recogidas no eran beatas, por más que se las llamara popularmente así o por más que fray Félix deseara verlas convertidas en las primeras monjas profesas indias de Filipinas. Esto quería decir que la fundación era irregular, aunque las autoridades civiles y eclesiásticas de las islas no hubieran denunciado el hecho, y contemplaran con satisfacción sus frutos. Era evidente que tenían la obligación de pagar tributo, y las autoridades de hacer que así fuera. La decisión real sobre la petición de fray Félix tardaría algunos meses en llegar a las islas, pero los informes a los que alude el religioso no eran todos favorables a su proyecto, cosa que, tal vez, ignorara el religioso.

El caso es que todas estas consideraciones no se escaparon a la vista de los oficiales reales, a los que se había pedido un informe sobre el asunto. Después de revisar los padrones realizados en la numeración anterior de la provincia de Tondo, concluyeron que no había en ellos nada que aclarara si se incluyó o no a las mujeres del recogimiento de Pásig. Pero también añadieron que, en tanto llegara la aprobación real, las beatas tenían que pagar tributo y que, en lo relativo a la fundación, debían respetarse

\footnotetext{
21 Ibídem.

22 Fray Félix Trillo, al gobernador. Pásig, 30-I-1754. AGI, Filipinas, 198, N. 15.
} 
las regalías de la corona, tal y como establecía la ley $1^{\text {a }}$ del título 3 , libro I de la Recopilación.

Traer a colación esta ley no era baladí, habida cuenta de que fray Félix repetía que había solicitado al rey la autorización para transformar la casa en convento. Según dicha ley era requisito indispensable la aprobación real y se consideraba delito grave que, sin ella, las autoridades civiles toleraran el comienzo de una fundación. El deseo de convertir las casas de recogimiento en cenobios femeninos fue una constante en la historia de estas instituciones en Filipinas; en este sentido, el caso de Pásig no resulta excepcional, pero cabía plantearse si desde un principio fray Félix Trillo buscó sentar las bases de un futuro convento, sorteando las leyes. Así al menos lo apuntaron los oficiales reales, quienes afirmaron que el asunto tenía que ser estudiado por el fiscal de la Audiencia.

\section{LA DISPUTA EN TORNO A LA EXENCIÓN DEL TRIBUTO}

Entrado febrero de 1754, los documentos que componían el todavía pequeño expediente llegaron a manos del fiscal de la Audiencia. Su respuesta fue un extenso y contundente informe desmontando uno a uno los argumentos de fray Félix. Efectivamente, en su opinión, nada justificaba la exención que reclamaba el religioso; las llamadas beatas eran indias y, como tales, sujetas a la obligación de tributar. Ni su condición de recogidas, ni su piadoso modo de vida, ni su corto número, podían ser excusas para no hacerlo. Tampoco el que nunca antes se les hubiera intimado a ello, ni el que el arzobispo o los gobernadores conocieran la casa y la aprobaran, o el que, a instancias de fray Félix, hubieran enviado informes al monarca. A lo sumo, eso probaba que toleraban la existencia de dicha casa pero no más.

La fundación, por otro lado, había sido hecha sin la previa licencia real, y la ley $1^{\mathrm{a}}$, título $3^{\circ}$, libro I de la Recopilación establecía que en estos casos, las autoridades debían ordenar su demolición; ciertamente, esta ley se refiere a monasterios y no a casas de recogidas, pero ya hemos visto cómo fray Félix Trillo confundía interesadamente una cosa con la otra. Probablemente el fiscal vio en esto una buena ocasión para apostillar su rechazo a la exención de las beatas y añadir dureza a un informe que deja traslucir cierta molestia por algunas expresiones con las que dicho religioso había intentado dar solidez a sus argumentos.

Por eso, además de exigir de nuevo que se mostraran los documentos que autorizaban la fundación, y que como constaba en el expediente, no existían, llamó la atención sobre cierta información que había llegado a su conocimiento y que se refería a la profesión de votos por parte de las beatas y a la existencia de un "noviciado formal"; es decir, a prácticas no autorizadas y que manifestarían abiertamente la voluntad de transformar la casa en un auténtico convento. Para averiguar lo que realmente sucedía puertas adentro de la casa, el fiscal aconsejó la realización de una visita.

En cuanto a los tributos impagados, debían ser cobrados, ya que "estos malos ejemplares no pueden perjudicar el derecho de su majestad, y los que lo hacen y consienten están obligados a la restitución en conciencia, como de cosa legítimamente 
debida y no pagada" ${ }^{23}$. Por lo tanto, el gobernador debía ordenar al juez numerador de Tondo que incluyera a las mujeres en el padrón, consignara sus edades, estados y circunstancias, y les cobrara los tributos "sin privilegio ni excepción alguna" que, a su juicio, no se les debía conceder.

Pero, además, el fiscal aprovechó la ocasión para llamar la atención sobre la libertad que se tomaba fray Félix de recluir en la casa a mujeres sin más orden que la suya propia. Al hacerlo contravenía las leyes de Indias, en particular la ley $6^{\mathrm{a}}$, del título $13^{\circ}$, libro I de la Recopilación, que prohibía a los clérigos encarcelar y castigar a los indios, por no tener jurisdicción alguna ${ }^{24}$.

Aparentemente, el informe fiscal causó el efecto deseado: el gobernador firmó un decreto ordenando despachar un ruego y encargo a fray Félix Trillo instándole a que permitiera la numeración de las beatas y dándole un plazo de quince días para que exhibiera las licencias de erección. De no hacerlo así, se seguirían graves inconvenientes para la subsistencia de la casa ${ }^{25}$.

En cuanto a la visita, el gobernador concedió comisión al oidor don Francisco Henríquez de Villacorta para que en compañía del fiscal se desplazara a Pásig.

\section{LA VISITA DE LA CASA DE RECOGIDAS}

Fue realizada el día 28 de febrero, comenzando por el reconocimiento de la casa, un edificio de piedra con cubierta de teja, y "bastantemente capaz". Contaba con una sala utilizada como oratorio y cuarto de labor, y cuatro aposentos; tres de ellos eran dormitorios y el otro, una enfermería. También contaba con varias "oficinas", jardín, y en la planta baja, una sala grande que era empleada como escuela,

donde asisten las niñas del pueblo por las mañanas los días de trabajo a aprender la doctrina cristiana que les enseñan algunas mujeres de casa destinadas para este ejercicio, concurriendo frecuentemente crecido número de niñas, las que por las tardes se van a sus casas $^{26}$.

A continuación, fueron presentadas al visitador las mujeres que se encontraban entonces allí, menos tres o cuatro que estaban convalecientes en la enfermería y las que estaban impartiendo doctrina o atendiendo a los oficios de la casa. El número de las presentes era 90, incluyendo las niñas; 40 de ellas eran mujeres que permanecían "de asiento" en la casa. Tenían edades diversas y la mayor de todas, la única anciana, era la primera que se había recluido por voluntad propia; las 39 restantes tenían edades comprendidas entre los 15 y los 30 años, y en su mayoría eran huérfanas. En cuanto a

\footnotetext{
23 Vista del fiscal de la audiencia de Manila. Manila, 11-II-1754. AGI, Filipinas, 198, N. 15.

24 Era esta una cuestión sumamente compleja que daría lugar tres años más tarde a un sonoro enfrentamiento entre la autoridad civil y la eclesiástica. MANCHADO, 2011, pp.147-183.

25 Decreto del gobernador. Manila, 11-II-1754. AGI, Filipinas, 198, N. 15. Este mismo día se remitieron el ruego y encargo al padre Trillo y un despacho al juez numerador de Tondo para que realizara la numeración de las beatas sin dilación.

26 Diligencias de la visita a la casa de recogidas del pueblo de Pásig. Pásig, 28-II-1754. AGI, Filipinas, 198, N. 15.
} 
las depositadas, eran 12; de ellas, cuatro estaban locas y dos estaban allí por "fatuas". El resto eran niñas educandas de 10, 15 y 17 años, la mayoría naturales de Pásig. De otros pueblos cercanos había 10 o 12 niñas más que se habían recogido en la casa a causa de una epidemia de peste. Otras pocas estaban, según afirmó fray Félix Trillo, a punto de casarse y por eso no se incluyeron en la cifra de las 90 .

Se interrogó a cuatro de ellas bajo juramento y con intérprete, acerca de los puntos que habían sido señalados por el fiscal; es decir, sobre si entraban libremente en la casa, si realizaban votos, si tenían libertad para irse, si vestían hábito y qué régimen de vida llevaban.

La primera en declarar fue la más anciana de todas, Sabina de Guzmán o de Jesús. Era natural de Maycavayan y viuda. Según afirmó, contaba 106 años de edad y llevaba recogida en la casa 15. Fue la primera en entrar en el recogimiento, cuando era apenas una pequeña habitación, que con el tiempo se fue ampliando. Parece que a su iniciativa, se constituyó el recogimiento al que se fueron agregando otras mujeres que querían vivir "aseguradas de los riesgos que había en el pueblo". Todas ellas permanecían libremente en la casa e incluso se habían negado a salir cuando sus padres habían intentado llevárselas. Aseguró que no hacían votos ni había ceremonias especiales para el ingreso, más allá de leerles un librito en el que se contenía el modo de vida que debían seguir, compuesto por fray Félix Trillo. Él les preguntaba en el momento de ingresar en la casa a qué venían, y contestaban que "a vivir en la casa hasta morir". No llevaban hábito sino que conservaban su modo tradicional de vestir, añadiendo, eso sí, la correa agustiniana descubierta sobre su lambong ${ }^{27}$.

La siguiente en declarar fue Gabriela Tuasón; ella era la encargada de custodiar el librito redactado por fray Félix y en el que, según su declaración, se contenían ejercicios espirituales y devociones distribuidas entre los días de la semana. Además, exhibió otros doce escritos en tagalo que fueron inspeccionados por el intérprete, al que se hizo declarar el contenido bajo juramento. Eran todos libritos en cuarto con oraciones y ejercicios piadosos.

Gabriela Tuasón contaba 25 años y había entrado voluntariamente en la casa en 1741. Aquí "estaba gustosa" y deseaba permanecer para siempre, como se lo había manifestado a fray Félix Trillo al ingresar. A través de su declaración conocemos el ritmo de vida de la casa, marcado por la oración y el trabajo. Según afirmó, se levantaban a las 4 de la mañana y marchaban a la iglesia hasta que acababan las misas, sobre las siete y media; entonces volvían a la casa y se dedicaban a coser u a otros trabajos, hasta las 10 de la mañana, hora a la que comenzaba la oración, que duraba hasta las 11 . Descansaban y comían entre las 11 y la 1 , y volvían a rezar hasta las 2. Desde entonces y hasta las 5 volvían a sus labores y de 5 a 7 reanudaban los rezos. Entonces cenaban y se acostaban a las 8 , levantándose a medianoche para el rezo del rosario.

Aseguró que, a causa de la mala salud de fray Félix, no recibían instrucción en castellano todos los días, pero que "algunas que saben un poco, suelen hablar algunas palabras”. Al igual que había declarado Sabina de Guzmán, afirmó que no había no-

27 El lambong era un sayo largo que llegaba hasta los pies. PriETO, 1993, p. 259. Declaración jurada de Sabina de Guzmán (o de Jesús). Pásig, 28-II-1754. AGI, Filipinas, 198, N. 15. ff.50v-51r. 
viciado, ni llevaban hábito, ni celebraban ceremonias especiales con ocasión de nuevos ingresos. Tampoco tenían señalados ejercicios cuyo incumplimiento acarreara un pecado mortal, lo que quería decir que no profesaban votos ${ }^{28}$.

De las cuatro declarantes, solamente María del Espíritu Santo pudo explicarse sin intérprete. Era natural de Binondo, de 17 años, y llevaba seis en la casa, donde al igual que sus compañeras, había entrado voluntariamente y permanecía allí "gustosa".

Que no hay diferencia ninguna en las que entran desde el día primero, más adelante no hay ninguna que mande, que todas son iguales, que no hay noviciados ni votos, que ningún ejercicio obliga a pecado ni se la ha dicho por el padre prior que tengan obligación de vivir perpetuamente en ésta, aunque no ha visto salir a ninguna ${ }^{29}$.

La visita de la casa concluyó a las 11 de la mañana, pero las diligencias no terminaron hasta que no se tomó declaración a fray Félix Trillo. De nuevo se le instó a mostrar las licencias de fundación del recogimiento, y de nuevo tuvo que reiterar que no las había solicitado. Ahora, sin embargo, fue un poco más explícito con respecto a la historia de la casa y a las razones que guiaron su comportamiento en este asunto. Así, aseguró que había sido puesta en pie gracias a la casualidad y que inicialmente se creó para dar refugio a las mujeres que lo necesitaban por diversas circunstancias. Con el paso del tiempo fue necesario hacer una casa mayor y más tarde, una tercera. No requirió ninguna licencia y sólo contaba con una patente del arzobispo en la que le encargaba que la cuidase con esmero. En su descargo aducía que había obrado así por desconocimiento de los trámites exigidos por las leyes y porque nadie le había dicho otra cosa. Una vez que supo de la necesidad de la autorización real de la fundación, acudió al rey, y pidió los informes que pudieran ayudarle a conseguir que el recogimiento permaneciera en el estado que tenía o que se transformara según la voluntad real.

En cuanto a las rentas de que disponía, señaló 200 o 300 cavanes de arroz, producto de algunas tierras, que consideraba suficiente para las mujeres que vivían en la casa según la regla de las terciarias agustinas calzadas, "con otras muchas que voluntariamente han añadido". El tiempo que les sobraba lo empleaban en enseñar y examinar de doctrina a las mujeres del pueblo; las más robustas pilaban el arroz para ayudar a mantenerse. Si bien no había profesiones religiosas, era cierto que se permitía hacer voto de castidad voluntario hasta que tomaran estado a las más aventajadas en virtud; también, que dicho voto lo tenían la mayor parte de las mujeres recogidas ${ }^{30}$.

28 Declaración jurada de Gabriela Tuasón. Pásig, 28-II-1754. AGI, Filipinas, 198, N. 15. f. 54v.

29 Declaración jurada de María del Espíritu Santo. Pásig, 28-II-1754. AGI, Filipinas, 198, N.15. ff.56v57r. En cuanto a la cuarta declarante, Policarpia Francisca de Castro, era natural de Quingua y llevaba tres años en la casa. Su declaración es la más breve ya que, como se hizo constar: "aunque entiende algo castellano, se explica dificultosamente y da poca razón de lo que se le pregunta”. Pásig, 28-II-1754. AGI, Filipinas, 198, N. 15 , f. 56 r.

30 Declaración jurada de fray Félix Trillo. Pásig, 28-II-1754. AGI, Filipinas, 198, N. 15, ff. 58v-61r. 


\section{EL DEBATE SOBRE EL FUTURO DEL RECOGIMIENTO}

Las diligencias de la visita fueron entregadas al fiscal de la audiencia el primer día de marzo de 1754. Ciertamente él había participado en la inspección y parece que todo cuanto pudo observar le convenció de que el asunto era de mayor calado que una mera disputa por la exención del tributo. Efectivamente, en su informe expresó su convencimiento de que lo que se estaba tramando era la fundación de un convento, para lo cual se iba disponiendo todo, a la espera de la autorización real. Siendo esto así, lo que procedía era dar cumplimiento a la ley $1^{\text {a }}$ del título $3^{\mathrm{a}}$, libro I de la Recopilación, que ordenaba la demolición de la casa ${ }^{31}$. En este punto el fiscal no toma en cuenta que dicha ley también ordenaba el regreso de la fundación al estado en que se encontrara antes de haber sido transformada en monasterio, tal vez porque sabía que no contaba con licencia en absoluto y, por lo tanto, había un defecto fundamental en la obra de fray Félix Trillo.

El caso es que también trajo a colación la ley 19 del título $3^{\circ}$, libro I en la que se ordenaba a los virreyes que fundaran y protegieran a las casas de recogimiento, que debían tener una finalidad educativa. Apoyado en ella, el gobernador podría autorizar la subsistencia de la casa de Pásig, en tanto llegaba la decisión real sobre el asunto. Eso sí, ajustada a lo establecido por las leyes, que en síntesis era lo siguiente: sujeción al Real Patronato, mantenimiento de la casa con los recursos que arbitrara fray Félix "sin perjuicio de los naturales, leyes de estos reinos y de otro tercero alguno" y, por supuesto, sin ser onerosa para el real erario. Además, el número de mujeres residentes en la casa debía ajustarse a lo que determinara el gobernador o quien ostentara el vicepatronazgo, absteniéndose el padre Trillo de admitir a ninguna otra; que sólo hablaran la lengua castellana y no hicieran uso de libros en tagalo; que se sometiera a visitas periódicas; que no se les impusiera la regla de la tercera orden, sino que los ejercicios espirituales se les propusieran como meras actividades piadosas y que se les atemperaran "a la delicadeza de su natural sexo y poca robustez, que por lo regular se reconoce en la gente de estos países, dejándoselos en la estimación y concepto de obras piadosas y cristianas, que sean compatibles con la vida política secular, por si algún día quisieren salir a tomar estado" 32 . Finalmente, los libros escritos en tagalo y que tenían en su poder debían ser recogidos y traducidos fielmente al castellano; especialmente el que contenía el modo de vida seguido en la casa, el cual debía ser inspeccionado por el fiscal "pues en la visita no se hizo por falta de tiempo para cosa tan prolija y de buen intérprete" 33 .

Este escrito del fiscal fue remitido al asesor del gobierno, quien en un extenso informe justificó la necesidad de mantener el recogimiento. Se inició así un enfrentamiento entre ambos que evidencia no sólo la existencia de opiniones contrapuestas, sino cierta antipatía del fiscal hacia dicho asesor.

31 Leyes $1^{\mathrm{a}}$, tít. $3^{\mathrm{o}}$, Libro I, y $1^{\mathrm{a}}$ y $2^{\mathrm{a}}$, del título $5^{\mathrm{o}}$, libro I de la Recopilación. Las dos últimas citadas se refieren realmente a la decencia del culto y a la inmunidad de lugares sagrados.

32 Informe del fiscal de la audiencia de Manila. Manila, 5-III-1754. AGI, Filipinas, 198, N. 15, f. 67v.

33 Ibídem, f. 69r. 
El informe del asesor se fundamentó jurídicamente sobre las leyes 19 del título $3^{\circ}$, libro I y la $4^{\mathrm{a}}$ del título $4^{\mathrm{o}}$ del libro VII de la Recopilación. La primera se refería, como ya se ha señalado, a la fundación y protección de las casas en que se recogía y enseñaba a las indias doncellas, y a las características que debían tener. En cuanto a la segunda, se refería a la fundación de casas para jóvenes huérfanas que debían mantenerse con su hacienda o con limosnas. El asesor entendía que ambas justificaban la conservación del recogimiento de Pásig, a pesar de que se hubiera erigido sin licencia y de que las mujeres vivieran según la regla de San Agustín y profesaran voto voluntario de castidad. La buena voluntad de fray Félix y los frutos producidos por la casa cohonestaban los defectos jurídicos detectados en su fundación. Se añadía, además, que había contado con la aprobación de los gobernadores, quienes la habían visitado en repetidas ocasiones, ya que Pásig era "el Aranjuez de sus vacaciones". También los arzobispos conocían su existencia y la aprobaban, lo que era una garantía puesto que "lo que los varones doctos y graves ejecutan o permiten, se debe reputar por justo".

Por otra parte, los beneficios de dicha casa no se limitaban al aspecto espiritual, con ser estos notables. La educación que se proporcionaba a las mujeres las capacitaba para una vida familiar ordenada sobre la que descansaba la armonía marital y social. Además, la casa daba seguridad a aquellos padres que, cuando debían ausentarse (por los cortes de madera, el servicio en la milicia o en Cavite), dejaban a sus hijas a resguardo allí y "en mejor positura para casarse con españoles, que suelen muchas veces casarse con mestizas sangleyas".

Por otra parte, había demasiadas mujeres y esto era un peligro que había que solucionar:

... para cada indio corresponden tres o cuatro mujeres, y este vicio de la naturaleza se debe amoldar y refrenar para evitar los peligros de la relajación; porque la abundancia ruda y licenciosa corrompe a los hombres y a todas las familias, porque una mujer mala es el naufragio del varón, un cautiverio de la vida, una tempestad de la casa y un mal necesario, porque si la tierra inculta produce abrojos y espinas, ¿qué pueden hacer las indias libres cuando son muchas respecto de los varones, y estos regularmente dispersos? (...) es muy conveniente la abreviada escuela de esta casa, donde la política las desbaste, la virtud las ilustre y el temor de Dios las refrene ${ }^{34}$.

La casa debía, por tanto, mantenerse en la forma establecida por las leyes, y para eso resultaba preciso que se atuviera a las condiciones señaladas por el fiscal, y que, además, fuera dirigida por un religioso agustino "de la mayor virtud y ejemplo".

En cuanto al asunto de los tributos, el asesor se manifestó totalmente contrario al fiscal. Entendía que la notoria pobreza de las indias las eximía de dicha obligación. A ello se sumaba que nunca lo habían pagado y que, de obligarlas a hacerlo, la suma obtenida sería muy pequeña (unos 25 pesos anuales estimaba el asesor) porque la mayor parte de las residentes en la casa estaban exentas por edad, enfermedad u otras circunstancias.

34 Informe del asesor del gobernador, doctor don Domingo de Neyra. Manila, 12-III-1754. AGI, Filipinas, 198 , N. 15 , ff. $76 \mathrm{v}-77 \mathrm{r}$. 
Para el asesor debía tenerse en consideración que se dedicaban a rezar y a ejercicios piadosos y, en tanto permanecieran en el recogimiento, debían estar libres de la obligación de tributar. Entendía que la liberalidad del monarca así lo admitía y que ellas debían disfrutar de dicha exención, en la que se les manifestaba el aprecio real a la vida de comunidad y oración que llevaban. Hasta tal punto esto debía ser así que, reconociendo su condición de tributarias y la justicia con la que el fiscal pedía que se las incluyera en el padrón, no se debía obligarlas a pagarlo, en tanto no tomaran estado; es decir, en tanto no abandonaran la casa.

... si se obliga a tributar a estas indias mientras leen libros, rezan y aprenden, es ponerles en ocasión a que aborrezcan la virtud y desprecien las buenas costumbres, lo que no se debe permitir, sino que antes bien, se deben conservar en esta franqueza y utilidades de la posesión en que se hallan ${ }^{35}$.

Pero el asesor fue más allá al defender no sólo que estuvieran exentas del pago de tributos, sino que en atención a su eficaz influjo sobre las comunidades indias, al que constituye en garante del orden y la paz, fueran beneficiadas con el residuo de las cajas de comunidad del pueblo. Entendía que si los recogimientos como el de Pásig se multiplicaran en las provincias, se conjuraría el peligro de levantamientos indios. Por eso era bueno fomentarlos y, a tal fin, sugirió que se establecieran otras casas semejantes en las cabeceras de las provincias, para lo que había de enviarse un ruego y encargo a los superiores de las órdenes religiosas de Filipinas.

En cuanto a los libros de uso de las mujeres escritos en tagalo, consideró que bastaría con que fray Félix Trillo manifestara los libros castellanos que en adelante se usarían y la norma de vida de la casa para el futuro, a fin de evitar los gastos derivados de la traducción literal y ahorrar el tiempo que exigiría trasuntarlos todos.

Antes de que el asunto pasara al real acuerdo, como propuso el asesor, se solicitó un informe a fray Félix Trillo; corría ya el mes de marzo de 1754 y parecía que el asunto se acercaba a su definitiva resolución.

Fray Félix aprovechó esta ocasión para argumentar en favor de la casa que él había establecido con la sola intención, según reiteró, de dar solución a los problemas de moral pública provocados por las idas y venidas de mujeres de vida deshonesta, y para atender a la doctrina de las niñas y jóvenes del pueblo. Por este medio no sólo había resuelto las necesidades de Pásig, sino que había extendido su benéfico influjo a las localidades próximas, de donde los padres traían a sus hijas para ser instruidas. En cuanto a las mujeres "inquietas", la mayoría había corregido su comportamiento y muchas ya no querían abandonar la casa. Otros problemas, ya apuntados anteriormente, también habían encontrado una vía de solución a través de esta casa, surgida como un mero recogimiento; eso sí, de forma totalmente irregular por fundarse a espaldas de las leyes. En este punto resulta difícil creer que el padre Trillo y la jerarquía de su orden en las islas desconocieran los trámites legales requeridos para proceder a la fundación, tratándose todo lo relativo al Real Patronato de una cuestión de extraordinaria importancia que estaba siempre en boca de todos. Lo más probable no

\footnotetext{
35 Ibídem, f. 82r.
} 
es que ignorara que debía preceder la autorización del vicepatrono, sino que pensara que ésta se lograría a posteriori, como en otras ocasiones y en otros asuntos había sucedido repetidas veces en Filipinas.

El nuevo alegato de fray Félix puso empeño en dos cuestiones: deshacer el enojo del fiscal, provocado por ciertas expresiones suyas vertidas en escritos anteriores, y explicar algunos particulares relativos al funcionamiento de la casa, malinterpretados durante la visita realizada.

En cuanto al primer asunto, resultaba evidente que el fiscal se había sentido aludido por afirmaciones irónicas o despectivas del fraile. De ahí que ahora pusiera buen cuidado en dejar claro que no se había referido a él, sino al comportamiento extemporáneo y hostil del alcalde de Tondo. La sorpresa que le produjo la noticia de que, por primera vez, se numeraría a las mujeres recluidas en un recogimiento, junto a su terrible estado de salud, añadieron aparentemente mordacidad a unas palabras malinterpretadas.

Cuanto digo no es ni por imaginación por dicho señor fiscal, sí por el alcalde de Tondo, quien pasando por aquí como un trueno cuando se comenzaba la cuenta, amenazó por medio del escribano de ella al juez que si no empadronaba las beatas, se presentaría al gobierno. Pregunté entonces si se había empadronado las otras casas de recogidas que hay en esta provincia y cuyos pueblos ya habían empadronado, y me dijeron que no, por lo que atribuí a dicho alcalde por entonces ser el promovedor en este asunto. [...] confieso que hice mal en poner semejantes cláusulas en dicha carta, pero ni en estas ni en otras que contiene ¿cómo podía yo dirigirlas al señor fiscal y más necesitándole tanto, no sólo en este asunto, sino en otros muchos para bien de los indios y recta administración? ${ }^{36}$

Con respecto a ciertos pormenores de la visita, el padre Trillo asegura que la sorpresa confundió a las mujeres "que obraron en algunas cosas lo que no debían". Así, en cuanto a los libros, solamente exhibieron los escritos en tagalo, olvidando los españoles, y no manifestaron la insistencia del religioso en que perfeccionaran su conocimiento del español. De hecho, muchos de los ejercicios piadosos que realizaban los habían tomado de libros espirituales que tenían en español porque, aunque sólo una era capaz de hablarlo con fluidez, las demás lo entendían bastante bien. Por otra parte, la posibilidad de cotejar unos textos con otros era un buen recurso para perfeccionar sus conocimientos de esta lengua, por lo que quitarles los tagalos sería contraproducente. En cuanto a la forma de ingresar en el recogimiento, obviaron decir que algunas mujeres se volvían a su casa al segundo o tercer día, al no acomodarse al régimen de vida que se seguía. Aquellas que manifestaban su deseo de permanecer, recibían la correa bendecida y se les explicaban los beneficios e indulgencias que obtenían, "por cinturatas o terceras, que son las mismas que ganan las terceras de nuestro padre Santo Domingo, nuestro padre San Francisco y de Nuestra Señora del Carmen”, al tiempo que se les explicaba que no estaban obligadas a precepto alguno, más allá de

36 Informe de fray Félix Trillo. S.1., s.f. (Probablemente en Pásig, a 13 de marzo). AGI, Filipinas, 198, N. 15 , ff. $92 \mathrm{v}-93 \mathrm{r}$. 
guardar la propia regla, pudiendo abandonar libremente el recogimiento "sin dejar de ser tales terceras, como lo son otras muchas que viven con sus padres" ${ }^{37}$.

Un aspecto muy interesante del alegato de fray Félix es la respuesta que da a las exigencias planteadas por el fiscal como requisito indispensable para mantener abierta la casa de Pásig. Aparentemente, aquel acepta todo realizando algunas matizaciones en lo relativo al aspecto económico; es decir, avisa de una fundación hecha por la marquesa de Montecastro, insigne benefactora, por un importe de 300 pesos anuales para el mantenimiento de las recogidas. También de que, en tanto la renta se comenzaba a cobrar, dicha señora y su esposo acudían a las necesidades de la casa. Sin embargo, obvia la sujeción de la fundación al Real Patronato y la consiguiente aprobación de los ingresos de nuevas mujeres por el gobernador, en su calidad de vicepatrono. Así, únicamente dice que nunca se había sobrepasado ni se sobrepasaría el número que pudiera mantenerse cómodamente con las rentas disponibles, a las que se sumaban las aportaciones de los padres de las educandas. Pero no hay un acatamiento expreso a la prohibición de que el religioso libremente aceptara en la casa otras mujeres "sean de la clase que sean" ${ }^{38}$. Fray Félix fue consciente de ello e intentó justificarse alegando que el primer objetivo que tuvo al establecer la casa fue dar solución al problema que suponía la libertad de movimientos de mujeres de costumbres "estragadas" y su mal ejemplo. Se trataba de un problema común a muchos pueblos y la forma de combatirlo era recluirlas hasta que se enmendaran. Esta práctica, que según reconoce, tenía visos "de meter la hoz en jurisdicción ajena" en realidad era una forma de luchar contra el vicio y de colaborar con las autoridades civiles.

La dificultad puede estar en aquellas picaronas que más pueden llamarse diablos que mujeres, siendo el lazo de tantos solterones como hay en los pueblos; a éstas las prende el capitán, pero ¿dónde las ha de poner? La cárcel es una casilla de nipa donde están otros tan buenos como ellas; de depósito ya tengo dicho que no le hay seguro; remitirlas a Manila tiene tantas dificultades que su ejecución jamás se logrará, por lo que me pide licencia para meterlas en la casa de recogidas, y yo se la doy, en lo que no me parece vulnero la jurisdicción real, antes sí coadyuvo a sus ministros gastando el alimento para mantenerlas, con lo que se han refrenado tanto que ha años que sólo a una he visto en este pueblo, siendo antes muchas ${ }^{39}$.

\section{LA RESOLUCIÓN DE LA AUDIENCIA DE MANILA}

Antes de emitir el voto definitivo sobre el asunto del pago de los tributos, el real acuerdo celebrado en 28 de marzo evacuó un voto consultivo, solicitando la incorporación al expediente de la numeración de las mujeres residentes en la casa de Pásig. Esta relación, fechada el último día del mes de abril, proporciona información muy cumplida e interesante sobre quiénes compartían el día a día bajo el mismo techo.

37 Ibídem.

38 Vista del fiscal de la audiencia. Manila, 5-III-1754. AGI, Filipinas, 198, N. 15, f. 67.

39 Informe de fray Félix Trillo. S.1., s.f. (Probablemente en Pásig, a 13 de marzo). AGI, Filipinas, 198, N. 15, ff. 101v-102r. 
Así, sabemos que en la casa había 42 "beatas", la mayoría de las cuales procedía del mismo pueblo; tan sólo una venía de Binondo, y dos de Tambobo. Todas ellas eran indias, menos una mestiza de español (Policarpia Francisca de Castro, la única de la que no se precisa su edad). Excepción hecha de Sabina de Guzmán, que contaba con 106 años, las demás tenían edades variadas que oscilaban entre los 41 y los 13 años. De todas ellas, (salvo de la más anciana y la mestiza de español) conocemos el barangay del que procedían, y de bastantes, algunas circunstancias personales, como su condición de huérfanas de padre (15). En cuanto a su posible inclusión en el padrón de tributantes, 13 constan como reservadas: por edad (una), o por padecer diferentes enfermedades (tisis (cinco), héticas (dos), mal de Lázaro (dos), mal de lamparones (una), enfermedad habitual (una), por ser "simple" (una)). También, lógicamente, estaba exenta la mestiza de español y aquellas que aún eran menores de edad (17). Sin embargo, sólo se señala expresamente a dos como tributantes, a las que les correspondía pagar medio tributo. Las razones de la exención de las nueve restantes no se indican, aunque el real acuerdo posteriormente afirmó que se debía a su "falta de edad", lo que a todas luces no es cierto.

En la casa había también mujeres recogidas que no seguían "el rigor de la observancia de la casa"; se trataba de once mujeres, de edades comprendidas entre 14 y 20 años. Es posible que la única que se encontraba en situación de pagar el tributo lo hiciera en el barangay al que pertenecía, pero nada nos dicen los documentos al respecto.

Según consta en la lista, se educaban en la casa un total de 26 niñas y jóvenes; la más pequeña de las cuales contaba ocho años de edad, mientras que la mayor tenía 20. Sabemos que procedían de Pásig, pero también de diversos barrios anejos, y de otros pueblos, lo que acredita el atractivo que ejercía la casa como centro de enseñanza entre las poblaciones vecinas ${ }^{40}$.

Esta numeración fue remitida al gobernador el día dos de mayo, y dos más tarde un decreto suyo la trasladaba al real acuerdo. En tanto se tomaba una decisión definitiva sobre el asunto, el fiscal volvió a insistir en que se debía exigir el tributo, y solicitó que se contrastase la lista remitida con las numeraciones anteriores, a fin de esclarecer si anteriormente lo habían pagado. Al fiscal no se le quitaba de la cabeza que se trataba de una estafa bajo capa de piedad religiosa: las mujeres se escapaban del pago del tributo, y los religiosos contaban con un número mayor de asistentes, en tanto se lograba el objetivo final que era la fundación de un convento, bajo la dirección de los agustinos.

Que es uno de los fines con que se van aplicando a erigir semejantes casas para conseguir lo que por otra parte les está prohibido [...] asegurando esas mujeres que les cuiden y laven la ropa de la iglesia y conventos y hagan la que necesitan ${ }^{41}$.

Para el fiscal, debían pagar el tributo, lo hubieran hecho antes o no, e independientemente de que alegaran en su descargo que eran pobres y que se mantenían

40 Numeración realizada por don José de Artiaga, juez numerador de los reales tributos de la provincia de Tondo y su justicia mayor. Sitio de Anloagui, 24-IV-1754. AGI, Filipinas, 198, N. 15.

41 El fiscal de la audiencia, al gobernador. Manila, 10-V-1754. AGI, Filipinas, 198, N. 15. 
del trabajo de sus manos. Se trataba de una regalía que no podía verse afectada ni por la prescripción ni por la costumbre contraria, caso de haberse establecido así en las islas, lo que no terminaba de quedar claro. Efectivamente, fue la insistencia del fiscal la que llevó al gobernador a ordenar realizar la comprobación pedida; es decir, contrastar unas listas con otras, para averiguar si las mujeres recogidas habían sido incluidas anteriormente en el padrón de tributantes.

Hecho el escrutinio, lo que únicamente resultó fue que en las dos numeraciones anteriores de las provincias de Tondo y Cavite habían sido incluidas mujeres de toda condición y pagaban, por tanto, el tributo señalado, y que no constaba excepción alguna por motivo de pobreza. Esto sucedía el día 16 de mayo, y dos después fue remitido el expediente al asesor del gobierno para un nuevo informe. Este consistió, en esencia, en trasladar el asunto de nuevo al real acuerdo, pero aprovechó para responder a las puyas que le había lanzado el fiscal, por las florituras verbales y las digresiones de su anterior informe. Según afirmó el asesor, en uno anterior sobre el buyo, había incorporado "algunas notas de erudición", que le habían hecho acreedor a la "especial expresión" del Consejo y del propio rey ${ }^{42}$. Indudablemente, consideró que también en esta ocasión cabía recurrir a una oratoria florida y a ejemplos que, para el fiscal, estaban cogidos por los pelos.

Pero cuando ya el asunto se encaminaba a su resolución, al caso de las mujeres que vivían en la casa de Pásig se le vino a sumar el de otra pequeña comunidad de recogidas establecida en el pueblo de San Sebastián de Calumpan. Por lo tanto, la decisión que se tomara en el primero había de ser extensiva por fuerza al segundo. El fiscal insistirá que en ambos casos debían pagar el tributo que, además, era pequeño. Efectivamente, por lo que atañía a San Sebastián, se había realizado una numeración en marzo que había establecido la condición de tributantes de 11 de las 12 beatas, ya que la restante tenía padres y no había alcanzado la edad requerida ${ }^{43}$.

El expediente fue visto en el real acuerdo celebrado el último día de mayo de 1754. Éste resolvió que el gobernador podía mantener la casa abierta, pero ajustada en todo a la ley 19 , título $3^{\circ}$, libro I de la Recopilación, lo que suponía que tenía que someterse al Patronato Real y, como manifestación incuestionable de ello, correspondería al gobernador determinar el número de mujeres recogidas y aprobar sus ingresos. Sin embargo, el real acuerdo sólo especificó en este punto que el gobernador señalaría el número de mujeres que actuarían como maestras, pero nada más. En cuanto a los tributos, se estimó que no debían pagarlos; las razones aducidas fueron su pobreza y la consiguiente necesidad de limosnas, el que nunca lo habían pagado, que la cantidad resultante era nimia, y que también estaban exentas las mujeres que "el ordinario eclesiástico tiene en su casa de recogidas que está aprobada por su majestad" ${ }^{44}$.

42 Parecer del asesor del gobierno, doctor don Domingo de Neyra. Manila, 20-V-1754. AGI, Filipinas, 198, N. 15. El buyo es una enredadera aromática cuyas hojas, mezcladas con cal viva y el fruto de la palma llamada bonga, era masticado por los filipinos. Tan grande era su consumo que se constituyó en renta estancada. Sobre sus cualidades y efectos, véase Delgado, 1892, pp. 668-669.

43 Respuesta del fiscal. Manila, 22-V-1754. AGI, Filipinas, 198, N. 15.

44 Real acuerdo extraordinario de la audiencia de Manila, 31-V-1754. AGI, Filipinas, 198, N. 15. Se refería al conocido como beaterio de la Compañía de Jesús. 
El gobernador se conformó con esta decisión y se apresuró a poner en marcha el proceso de nombramiento de las maestras, cuatro o cinco, que debían tener más de cuarenta años y ser de buena vida. Fray Félix Trillo debía proponerlas, escogiéndolas de entre "las más expertas y ladinas en saber hablar en idioma castellano, y escribir y leer en él, si fuere posible" ${ }^{45}$. La notificación con que se dio cuenta al fiscal de la decisión del gobernador fue respondida con un escrito en el que éste advertía de que, como había podido comprobar durante la visita realizada a la casa, ninguna de las mujeres que residían en ella conocía el castellano lo suficiente como para ejercer de maestra; también de que, mientras no se les quitasen los libros en tagalo (que eran los únicos que usaban) no se cumpliría la orden del gobernador, ni la ley, continuarían viviendo según la regla de las terciarias agustinas, y terminarían por constituirse en convento, como aseguraba había sucedido con el beaterio de Santa Catalina de Sena, de Manila ${ }^{46}$.

La advertencia del fiscal no cambió nada, únicamente hizo que, previo un nuevo informe del asesor, el gobernador pidiera a fray Félix que propusiera como maestras a mujeres que supieran el castellano, fueran de la casa o de las indias del pueblo, "o de otra manera" (que no entra a especificar). La retirada de los libros tagalos y el cumplimiento de la ley 19 mencionada por el real acuerdo en su voto, serían la garantía de que la casa no deviniera en convento por la inercia de los hechos ${ }^{47}$.

\section{EL ASUNTO EN EL CONSEJO DE INDIAS Y LA RESOLUCIÓN DEL CONTENCIOSO}

El asunto llegó al Consejo en septiembre de 1755; tanto el gobernador como el fiscal de la audiencia remitieron una copia del expediente completo, acompañada de sendas cartas en las que explicaba, el primero, las medidas adoptadas, y el segundo, las razones que le habían llevado a empeñarse tanto en un asunto que sólo se entendía completamente en el contexto filipino, en el que se multiplicaban las casas de recogimiento de mujeres, llamadas vulgarmente "beaterios".

Efectivamente, como denunció el fiscal de la audiencia de Manila, el caso de Pásig no era único, y la exención de tributos con que se le había favorecido se había concedido también a la casa de recogidas del pueblo de san Sebastián de Calumpang. En ella vivían doce indias según la regla de terciarias o mantelatas recoletas, bajo la administración de la provincia de San Nicolás de Tolentino ${ }^{48}$. A más abundamiento, se había hecho público que otra casa de características similares, en la propia Manila, conocida como "beaterio de la Compañía", se regía por unos estatutos redactados por

\footnotetext{
45 Decreto del gobernador. Manila, 5-VI-1754. AGI, Filipinas, 198, N. 15.

46 Respuesta del fiscal a la notificación del decreto del gobernador de 5-VI-1754. Manila, 6 de junio. AGI, Filipinas, 198, N. 15. El beaterio de Santa Catalina no llegó a ser convento pero los dominicos mantuvieron un duro enfrentamiento con el arzobispo a cuenta de la clausura y la profesión de votos. Véase RUBIO, 1958, pp. 339-345.

47 Parecer del asesor del gobierno. Manila, 10-VI-1754. AGI, Filipinas, 198, N. 15. Dos días después, el gobernador firmó el correspondiente auto, y el día 14 se expidió el ruego y encargo a fray Félix Trillo.

48 Sobre esta fundación, véase Santiago, 1989, pp. 212-251.
} 
el arzobispo, sin intervención del gobernador ${ }^{49}$. Las mujeres recogidas en estas casas quedaban reservadas del pago de tributos, y si bien se decía que la exención concluía al tomar estado, lo cierto es que, a decir del fiscal, no se conocía ningún caso, porque todas quedaban vinculadas de por vida por los votos profesados. Esto perjudicaba no sólo a la hacienda real, sino también al Real Patronato, ya que tales fundaciones escapaban al control del vicepatrón, y tendían a convertirse de facto en auténticos beaterios y conventos, en un proceso fomentado por las propias órdenes religiosas.

Estas consideraciones fueron tomadas en cuenta por el Consejo de Indias en la consulta elevada al monarca, pero no hasta el punto de desaprobar lo actuado por el gobernador. Efectivamente, el Consejo consideró que aquel debía velar para evitar cualquier fraude, pero aprobó la existencia tanto de la casa de Pásig como de la de San Sebastián, y, asimismo, la exención de tributos, justificándola en que nunca se les había cobrado, en que debían recurrir a limosnas para mantenerse, y en la voluntad de la corona de fomentar la apertura de estos recogimientos; es decir, de casas de enseñanza que por su condición plenamente secular debían estar bajo el Real Patronato, como establecía la ley 19 , título $3^{\circ}$, libro I de la Recopilación. Al gobernador le correspondía autorizar la entrada en dichas casas del número de mujeres que se pudieran mantener y que fueran doncellas que se retiraban para formarse en las verdades de la $\mathrm{fe}^{50}$. La real cédula correspondiente fue firmada en Aranjuez, a 26 de mayo de $1756^{51}$.

Como sucedía con harta frecuencia, mientras en el Consejo se estudiaba el asunto, llegó a Manila la real cédula de 17 de noviembre de 1754, por la que se rechazaba la pretensión de fray Félix Trillo de convertir la casa de Pásig en un beaterio formal. Corría el mes de julio de 1755 cuando el real despacho fue solemnemente acatado y pasado a informe del fiscal. En Filipinas ya había un nuevo gobernador, don Pedro Manuel de Arandía, y fray Félix había fallecido ${ }^{52}$. El tenor de la real cédula aplacó la susceptibilidad del fiscal de la audiencia, ya que venía a insistir en la prohibición de transformar la naturaleza de la fundación; aún así, aconsejó la realización de una nueva visita a la casa, que sería encomendada al oidor don Fernando Dávila.

Esta inspección se retrasaría prácticamente un año, ya que no tuvo lugar hasta el mes de junio de 1756. En esta ocasión, el fiscal alegó obligaciones urgentes y no asistió a la visita de la casa que ahora llamaban "beaterio de indias tagalas y mestizas".

En este momento vivían allí 47 mujeres, doncellas y viudas. La que dirigía la casa, María Salomé, a la que se llama "principal o superiora", aclaró que cuatro estaban en la enfermería y dos más en Manila. A todas estas había que sumar siete que perma-

49 Distinguía a esta fundación de las otras existentes en Filipinas el hecho de que no dependían de una orden religiosa, porque los jesuitas tenían prohibido en sus constituciones hacerse cargo de este tipo de centros. Probablemente a esto se debe que el fiscal considere que este beaterio estaba "más ajustado a las reales leyes de Indias". El fiscal de la audiencia de Manila, don José Joaquín Merino de Rivera, al rey. Manila, 11-VII-1754. AGI, Filipinas, 198, N. 16. Véase Manchado, 2006-2007, pp.115-131.

50 Vista del fiscal del Consejo de Indias. Madrid, 30-III-1756. AGI, Filipinas, 198, N. 16.

51 AGI, Filipinas, 335, L.16/2/754-758.

52 Don Pedro Manuel de Arandía tomó posesión como gobernador de Filipinas el 19 de julio de 1754 y desempeñó el cargo hasta su muerte, acaecida el 1 de junio de 1759. CABRERo - LuQue - PALANCO, 2008 , vol. I, pp. 60-61. 
necían depositadas. Todas vestían al modo indio, sin hábito, y no profesaban votos. Después de la última visita realizada, no se habían producido nuevos ingresos

La inspección se completó con el interrogatorio de siete mujeres, entre ellas la directora, bajo juramento y por medio de intérprete. Todas eran doncellas tagalas, a excepción de una, Gabriela Tuasón, mestiza de sangley. Sus testimonios son concordantes en todo: no profesaban votos, podían abandonar la casa cuando quisieran y no se utilizaban libros en tagalo porque les habían sido retirados. Concluidos los interrogatorios, todas las mujeres fueron de nuevo reunidas para explicarles que al ingresar en la casa no lo hacían en una religión a la que quedaran vinculadas por votos solemnes.

La última diligencia de la visita consistió en la inspección ocular de las dependencias de la casa, que se halló, como en la ocasión anterior, bien cuidada. En cuanto a la escuela de niñas, el visitador pudo comprobar que recibían instrucción unas 70 u 80 , y que ésta se les impartía en castellano ${ }^{53}$.

Una vez concluida la visita, el testimonio de la misma pasó a manos del fiscal. A su juicio, el estado de la casa de recogidas se ajustaba a lo ordenado por las leyes y, aunque el visitador había obviado la inspección del régimen de vida de las recogidas y de los libros espirituales que utilizaban, se podía archivar el expediente. Únicamente había que recordar al padre ministro de Pásig que no recibiera a ninguna mujer recogida ni depositada sin mediar la autorización del gobernador, y que pusiera fin al abuso que había llegado a conocimiento del fiscal de la audiencia, consistente en que ciertos particulares enviaban a sus criadas a la casa, a modo de castigo ${ }^{54}$.

El 5 de julio del mismo año 1756, cuando se preparaba la salida del galeón, el fiscal informó al rey del cumplimiento de la real cédula prohibiendo la erección de un beaterio en la casa de Pásig; también lo hizo el gobernador, acompañando su informe de los autos de la segunda visita. Todos estos documentos llegaron al Consejo de Indias en febrero de 1758; en septiembre del mismo año, el Consejo se dio por enterado de todo, pero consideró que no había que tomar providencia alguna ${ }^{55}$. Para entonces el asunto se consideraba cerrado en España. En Filipinas, la casa de Pásig subsistiría hasta el fin del dominio español; eso sí, el número de mujeres recogidas fue descendiendo, al tiempo que se perdía la tensión espiritual de sus comienzos ${ }^{56}$.

53 “Cogió unas cartillas y las reconoció una por una, y las halló estar todas en lengua castellana”. Testimonio de la visita. Pásig, 9-VI-1756. AGI, Filipinas, 160, N. 5.

54 Vista del fiscal de la audiencia. Manila, 12-VI-1756. AGI, Filipinas, 160, N. 5. El correspondiente decreto del gobernador está fechado el día 14 de junio y fue notificado a fray Juan Facundo Meseguer, provincial de los agustinos calzados, en Tondo, a 22 de junio.

55 Consejo de 11-IX-1758. AGI, Filipinas, 160, N. 5.

56 Martínez de Zúñiga, que ejerció como ministro en Pásig a comienzos del siglo XIX, dice que vivían en la casa 50 mujeres, de las cuales 20 eran beatas y las demás, sirvientes y doncellas que se retiraban allí hasta que se casaban. Este religioso criticó duramente a las beatas, acusándolas de orgullosas y perezosas, y de consumir "en una infinidad de comodidades en la habitación, cama y comida" las pocas rentas de la casa, lo que impedía ejercer una más intensa actividad educativa. MARTínEZ DE ZúÑIGA, 1893, pp. 204-205. 


\section{CONCLUSIONES}

El estudio de los recogimientos filipinos, como el de otros tantos aspectos de la historia de la mujer, constituye un tema aún insuficientemente tratado por los historiadores. El estudio que aquí se ha presentado es una aportación al conocimiento de las formas de vida comunitarias femeninas que, en el caso del archipiélago filipino, gozaron de gran aceptación; en parte, porque eran la única posibilidad de satisfacer el anhelo de una vida de mayor perfección espiritual para las mujeres no españolas, y en parte, porque daban respuesta a otras necesidades no resueltas, como la educación, o la corrección y castigo de mujeres deshonestas. Las casas de recogimiento filipinas nunca recibieron el reconocimiento jurídico de beaterios, pero siempre tendieron a asumir modos de vida conventuales. Su historia se desarrolló, por tanto, en una permanente tensión incrementada por la desconfianza de autoridades civiles y eclesiásticas, que siempre temieron que generaran conflictos. El caso del recogimiento de Pásig ilustra perfectamente estas suspicacias y tensiones. El conflicto de los tributos remitía, en última instancia, al debate sobre la naturaleza jurídica de tales fundaciones, surgidas de modo irregular, ignorando las normas del Real Patronato. Es, por tanto, un conflicto jurídico (jurisdiccional) al que se dio una aparente solución mediante una real cédula firme en el tono, pero de dudosa efectividad en la práctica. La exención del tributo se impondría como una merced real, pero la naturaleza de estas fundaciones continuó siendo muy poco clara en el contexto filipino.

\section{REFERENCIAS BIBLIOGRÁFICAS}

Alonso Álvarez, Luis

2009 El costo del imperio asiático. La formación colonial de las islas Filipinas bajo dominio español, 1565-1800. México. Instituto Mora y Universidad de la Coruña, pp. 207-220.

Borges Morán, Pedro

1992a Historia de la Iglesia en Hispanoamérica y Filipinas. Tomo I. Madrid. Mapfre.

1992b Religiosos en Hispanoamérica. Madrid. Mapfre.

Cabrero Fernández, Leoncio - Luque Talaván, Miguel - Palanco Aguado, Francisco (coords. y dirs.)

2008 Diccionario Histórico, Geográfico y Cultural de Filipinas y el Pacifico. Madrid. AECI y Fundación Carolina, vol. I.

CAmacho, Marya Svetlana

2007 "Los beaterios y recogimientos en Manila en el siglo XVIII, acomodación religiosa y aportación social". En Viforcos MARINAS y LORETO LóPEZ (coords.), Historias compartidas. Religiosidad y reclusión femenina en España, Portugal y América. Siglos XV-XIX. León. Universidad de León, pp. 367-390. 
Cosano Moyano, Francisco

1985 Filipinas y su Real Hacienda (1750-1800). Córdoba. Monte de Piedad y Caja de Ahorros de Córdoba.

Delgado, Juan (SI)

1892 Historia General Sacro-Profana, Política y Natural de las Islas de Poniente, llamadas Filipinas. Parte Primera. Libro Primero. Manila. Imp. de El Eco de Filipinas.

García-AbÁsolo, Antonio

1991 "Pedro Calderón Enríquez, un magistrado crítico en Filipinas (1738-1766)". En Homenaje a Lourdes Díaz-Trechuelo. Córdoba. Publicaciones del Monte de Piedad y Caja de Ahorros de Córdoba, pp. 23-37.

LuQue AlCAIDE, Elisa

1970 La educación en Nueva España en el siglo XVIII. Sevilla. Escuela de Estudios Hispano-Americanos.

Manchado LóPez, Marta $\mathrm{M}^{\mathrm{a}}$

1999a "Religiosidad femenina y educación de la mujer indígena en Filipinas. El beaterio-colegio de la madre Paula de la Santísima Trinidad". Revista de Indias. Madrid, vol. LIX, nº 215, pp. 171-202.

1999 b "El proyecto de convento para mestizas de Santa Rosa de Lima, en Filipinas". Anuario de Estudios Americanos. Sevilla, tomo LVI, no 2, pp. 485-511.

2002 "Libertad personal y jurisdicción eclesiástica. Conflictos en torno al beaterio de Santa Catalina de Sena, en Filipinas". En IX Congreso Internacional de Historia de América. Tomo II. Mérida. Editora Regional de Extremadura, pp. 277-288.

2006-2007 "El beaterio de la Compañía de Jesús de Filipinas". Revista Española del Pacífico. Madrid, no 19-20, pp. 115-131.

2011 "Jurisdictional Conflicts Regarding the Ecclesiastical Prison of Manila during Governor Arandía's Term (1757-1758)". En Самасно (ed), Into the Frontier. Studies on Spanish Colonial Philippines. In Memoriam Lourdes Díaz-Trechuelo. Pasig City. University of Asia and the Pacific, pp. 147-183.

2012 "Un espacio para la mujer: notas para el estudio de los recogimientos y beaterios filipinos". Revista Hispanoamericana. Revista Digital de la Real Academia Hispano Americana de Ciencias, Artes y Letras. Cádiz, 2012, nº 2, pp.1-16.

Martínez Cuesta, Ángel (ORSA)

1993 "Monjas y beatas en Filipinas, 1621-1898". En Viforcos Marinas - Paniagua PÉREZ (coords.), I Congreso Internacional del monacato femenino en España, Portugal y América, 1492-1992. Tomo I. León. Servicio de Publicaciones de la Universidad de León, pp. 511-529.

MARTÍNEZ DE ZÚÑIGa, Joaquín

1893 Estadismo de las islas Filipinas o mis viajes por este pais. Tomo I. Madrid. Edición de W.E. Retana.

Molina, Antonio

1984 Historia de Filipinas. Tomo I. Madrid. Ediciones de Cultura Hispánica. 
Muriel, Josefina

1974 Los recogimientos de mujeres: respuesta a una problemática social novohispana. México. Universidad Nacional Autónoma de México. Instituto de Investigaciones Históricas.

1992 Las mujeres de Hispanoamérica: época colonial. Madrid, Mapfre.

Olaechea Labayen, Juan Bautista

1970 "Doncellas indias en religión”. Missionalia Hispanica. Madrid, nº 81, pp. 341-378.

Ortiz de la Tabla Ducasse, Javier

1974 El marqués de Ovando, gobernador de Filipinas (1750-1754). Sevilla. Escuela de Estudios Hispano-Americanos.

Prieto, Ana $\mathrm{M}^{\mathrm{a}}$

1993 El contacto hispano-indígena en Filipinas según la historiografía de los siglos XVI y XVII. Córdoba. Servicio de Publicaciones de la Universidad.

RECOPILACIÓN

1841 ---- de Leyes de los Reinos de las Indias mandadas imprimir y publicar por la Majestad Católica del rey don Carlos II. Tomo I. Madrid. Boix Editor.

Ramos Medina, Manuel (coord.)

1995 El monacato femenino en el Imperio español: Monasterios, beaterios, recogimientos y colegios. Homenaje a Josefina Muriel. México. CONDUMEX.

Rodríguez Rodríguez, Isacio

1979 Historia de la Provincia Agustiniana del Santísimo Nombre de Jesús de Filipinas. Vol. XI. Valladolid. Estudio Agustiniano.

Rubio Merino, Pedro

1958 Don Diego Camacho y Ávila, Arzobispo de Manila y de Guadalajara de México (1695-1712). Sevilla. Escuela de Estudios Hispano-Americanos.

SANTIAGO, Luciano (P.R)

1989 "Talangpaz: The foundresses of the Beaterio de San Sebastián de Calumpang (Now the Congregation of the Agustinian Recollect Sisters) 1691-1732”. En Philippine Quarterly of Culture \& Society. Cebú City, vol. 17, pp. 212-251.

2005 To Love and to Suffer. The Development of the Religious Congregations for Women in the Spanish Philippines, 1565-1898. Quezon City. Ateneo de Manila University Press. 